Keywords: Tank Closure

Grout

Retention: Permanent

\title{
Tanks 18 and 19-F Equipment Grout Fill Material Evaluation and Recommendations
}

D. B. Stefanko

C. A. Langton

November 2011

Savannah River National Laboratory

Savannah River Nuclear Solutions, LLC

Aiken, SC 29808

Prepared for the U.S. Department of Energy under contract number DE-AC09-08SR22470.

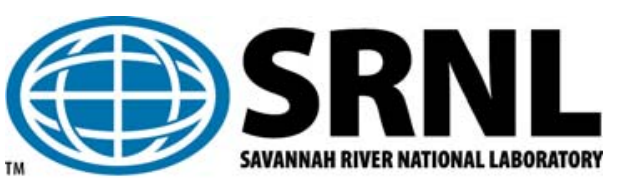


SRNL-STI-2011-00592

Revision 0

\section{DISCLAIMER}

This work was prepared under an agreement with and funded by the U.S. Government. Neither the U.S. Government or its employees, nor any of its contractors, subcontractors or their employees, makes any express or implied:

1. warranty or assumes any legal liability for the accuracy, completeness, or for the use or results of such use of any information, product, or process disclosed; or

2. representation that such use or results of such use would not infringe privately owned rights; or

3. endorsement or recommendation of any specifically identified commercial product, process, or service.

Any views and opinions of authors expressed in this work do not necessarily state or reflect those of the United States Government, or its contractors, or subcontractors.

\section{Printed in the United States of America}

Prepared for

U.S. Department of Energy 


\section{REVIEWS AND APPROVALS}

\section{AUTHORS:}

D. B. Stefanko, E\&CPT Research Programs

Date

C. A. Langton, E\&CPT Research Programs

Date

TECHNICAL REVIEW:

M. G. Serrato, E\&CPT Research Programs / SRNL

Date

APPROVAL:

H. H. Burns, E\&CPT Research Programs, Project Manager

Date

F. M. Pennebaker, E\&CPT Research Programs, Manager

Date

S. L. Marra, E\&CPT Research Programs, Manager

Date

R. C. Jolly, Jr., FY11 Closure Project Engineering, SRR, Manager

Date

P. E. Carroll, FY12 Closure Project Engineering, SRR, Manager

Date

J. E. Herbert, Waste Removal and Tank Closure, SRR Project Operations, Manager Date

B. A. Martin, Closure and Disposal Determination, SRR

Date 


\section{ACKNOWLEDGEMENTS}

The equipment-grout development work and recommendations described in this report were funded by SRR Project Engineering and SRR Project Operations to support the final closures of HLW Tanks 18-F and 19-F. Contributions from the following organizations were much appreciated and essential to this effort.

URS Washington Group, Quality and Testing Division management and technical personnel provided use of the SRS Civil Engineering Laboratory and testing equipment, and technical expertise and input that was essential for performing tests and obtaining the results in this report. W. Pope, Jr., W. B. Mhyre, and J. T. Waymer, URS, are recognized as key contributors to this project.

J. L. Steimke, H. N. Guerrero, M. L. Restivo and Z. Qureshi, SRNL Engineering Development, provided the thermal properties for selected mixes. This information was required for designing the equipment grout formulation. 


\section{EXECUTIVE SUMMARY}

The United States Department of Energy (US DOE) intends to remove Tanks 18-F and 19-F at the Savannah River Site (SRS) from service. The high-level waste (HLW) tanks have been isolated from the F-area Tank Farm (FTF) facilities and will be filled with grout to complete the closure. The grout will: 1) physically stabilize the empty volumes in the tanks, 2) limit vertical pathways from the surface to residual waste on the bottom of the tanks, 3) provide an intruder barrier, and 4) provide an alkaline, chemical reducing environment within the closure boundary to limit solubility of residual radionuclides [1].

Bulk waste and heel waste removal equipment will remain in Tanks 18-F and 19-F. This equipment includes: mixer pumps, transfer pumps, transfer jets, equipment support masts, sampling masts and dip tube assemblies. The current Tank 18-F and 19-F closure strategy is to grout the internal void spaces in this equipment to eliminate fast vertical pathways and slow water infiltration to the residual material on the tank floor [2].

This report documents the results of laboratory testing to identify a grout formulation for filling equipment in Tanks 18-F and 19-F, and was authorized under Task Technical Request (TTR), HLWTTR-2011-008 [3], and the TTQAP, SRNL-RP-2011-00587 [4].

The only requirement for grouting abandoned equipment is that the equipment should be filled to the extent practical $[1,2,3]$. General performance requirements for the equipment fill grout are listed below $[2,3]$ :

- The grout must be alkaline and chemically reducing, i.e., contain slag

- Flowable enough to fill equipment voids and pipes $\geq$ one inch in diameter

- Form a solid material upon curing

- Provide a barrier to infiltrating water, i.e., minimize arduous vertical pathways.

Additional material characteristics not specified in the TTR or closure module include:

- Pumpable slurry

- Compatible with the materials of construction of the equipment.

- No chemical or thermal reactions that over pressurize the equipment during or after filling.

- Homogeneous material.

The FTF Performance Assessment (PA) does not speak to the equipment or the equipment fill grout. ${ }^{\mathrm{a}}$ Consequently, parameters for the equipment fill grout are not required to satisfy the PA process. However, a series of experimental test protocols for evaluating and comparing the trial mixes were developed for the equipment fill grouts. These protocols provided physical and hydraulic property data to evaluate the trial mixes.

Per the TTR, the SRR cooling coil grout was selected as the base case mix. This grout is a mixture of Masterflow ${ }^{\circledR} 816$ cable grout, Grade 100 slag and water [5]. Two problems were encountered with the cooling coil mix: 1) high temperatures generated as the result of exothermic hydration reactions ${ }^{\mathrm{b}}$ and 2) flow behavior that was more suited for pressure grouting than for gravity filling. (Some of the

\footnotetext{
${ }^{a}$ The mesh size and discretization approach applied to the tanks in the finite volume PorFlow ${ }^{\circledR}$ code does not distinguish between bulk fill, equipment, and equipment fill grout. All of these materials are assigned bulk fill grout properties.

${ }^{b}$ Evidence of high temperatures was documented in the report describing the cooling coil grout (steam vents in grout cast into 55 gallon drums) and recommendations were provided for dissipating the heat, i.e. fill the cooling coils prior to filling tanks. In this study temperatures $>100^{\circ} \mathrm{C}$ were measured under adiabatic and semi adiabatic conditions. The equipment geometry and volumes dissipates less heat than cooling coils in an empty tank.
} 
equipment abandoned in the tanks has the same pathway for filling and venting and therefore gravity filling is the only option.)

The cooling coil grout was modified to reduce the amount of heat generated and to increase the flowability (reduce the ASTM C 939 flow cone time from $30+$ seconds to $<20$ seconds). Class F fly ash was substituted for up to 75 wt. \% of the MasterFlow ${ }^{\circledR} 816$ cable grout in the base case formulation. The water to cementitious ratio was also increased. Trial mix designs and properties are provided in this report.

Two mixes are recommended for the ADMP Tier 1A equipment fill mock up test. The ingredients and proportions are provided below.

\begin{tabular}{|c|c|c|}
\hline Ingredient & T1a-62.5FA.400 (wt. \%) & T1a-62.5FA.400 (lbs / cu ft) \\
\hline Masterflow $^{\circledR} 816$ & 24.35 & 26.48 \\
\hline Blast Furnace Slag, grade 100 & 6.49 & 7.06 \\
\hline Fly ash, Class F, ASTM C618* & 40.58 & 44.14 \\
\hline Water & 28.57 & 31.07 \\
\hline water/cementitious material & 0.40 & 0.40 \\
\hline
\end{tabular}

\begin{tabular}{|c|c|c|}
\hline Ingredient & T1a-75FA.400 (wt.\%) & T1a-75FA.400 (lbs / cu ft) \\
\hline Masterflow $^{\circledR} 816$ & 16.23 & 17.36 \\
\hline Blast Furnace Slag, grade 100 & 6.49 & 6.94 \\
\hline Fly ash, Class F, ASTM C618* & 48.70 & 52.07 \\
\hline Water & 28.57 & 30.55 \\
\hline water/cementitious material & 0.40 & 0.40 \\
\hline
\end{tabular}

$*$ Proportions assume a fly ash specific gravity of 2.22 .

Both mixes have properties that exceed the minimum strength and permeability set for the Tank 18-F and 19-F bulk fill grout [11]. T1a-62.5FA had a 16 seconds flow cone value whereas T1a-75FA had a 19 seconds flow cone rheology for mixes prepared under identical conditions in the laboratory. The advantage of the T1a-75FA mix is that it generates less heat during curing. The advantage of the T1a62.5FA mix is that it is slightly more fluid with the same water.

At this time, the ease of filling the ADMP is weighted higher than curing temperature which can be managed by engineering controls. Consequently, T1a-62.5FA is the preferred grout formulation even if both mixes fill the ADMP equipment mock up form. Both grout mixes will be pumpable.

Colloidal mixing is recommended for the ADMP Tier 1A equipment fill mock up test and for full scale equipment filling. The amount of mechanical energy imparted to the grout during mixing had an effect on the slurry rheology. Samples prepared by paddle mixing and a short period ( $\sim 30$ seconds) of high-shear mixing produced slurries with faster ASTM flow cone results than slurries produced by just paddle mixing. 


\section{TABLE OF CONTENTS}

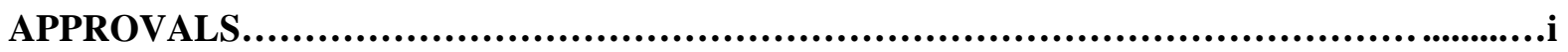

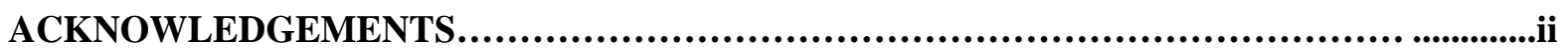

EXECUTIVE SUMMARY ............................................................. iii

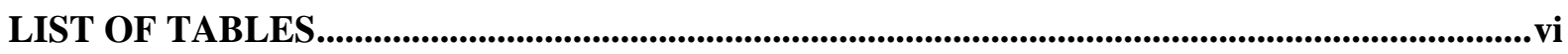

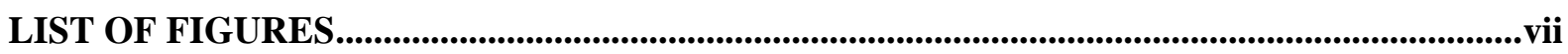

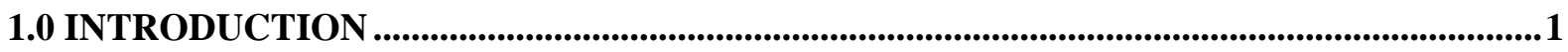

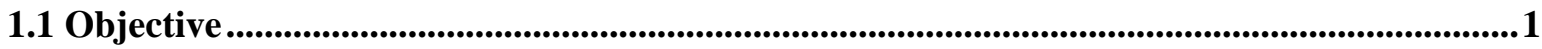

1.2 Background .........................................................................................................................................2

1.3 Previous SRS Experience with Equipment and Pipe Grouting ...................................................3

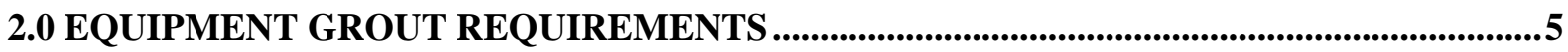

2.1 Equipment Grout Test Methods and Screening Criteria.......................................................5

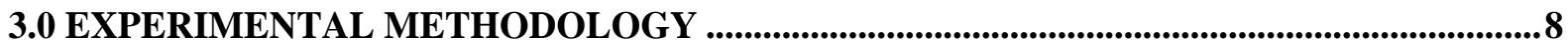

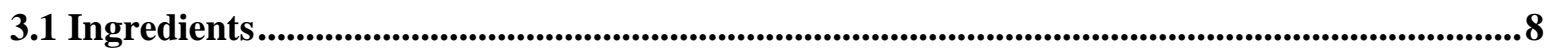

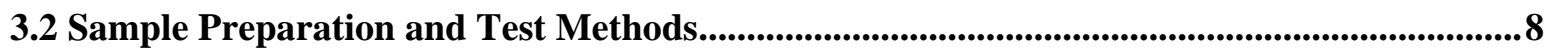

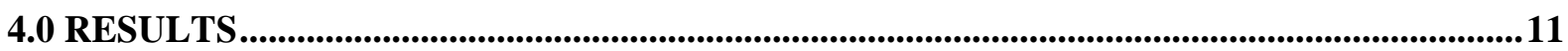

4.1 Phase 1: Cooling Coil Grout Base Case ..............................................................................11

4.2 Phase 2: Fly Ash Modified Cooling Coil Mixes...............................................................13

4.3 Phase 3: Water Extended - Fly Ash Modified Cooling Coil Series ......................................16

4.4 Additional Thermal Properties for Equipment Fill Grout Screening Mixes .......................17

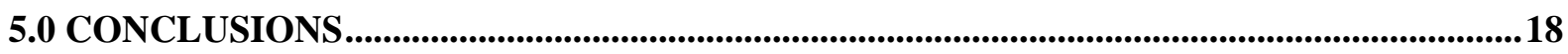

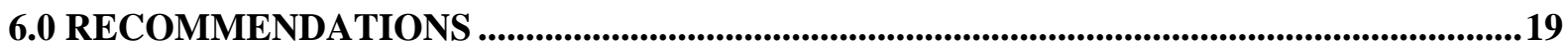

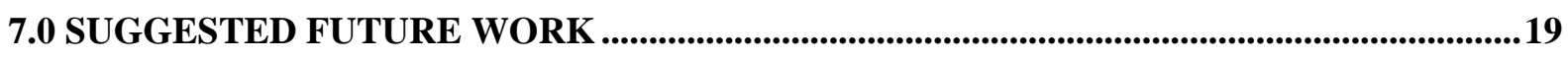

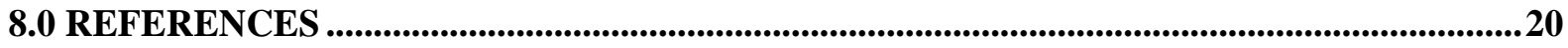




\section{LIST OF TABLES}

Table 1-1. Equipment suspended at tank risers and remaining in Tank 18-F. ................................3

Table 1-2. Equipment suspended at tank risers and remaining in Tank 19-F. ..............................3

Table 1-3. SRR tank closure cooling coil grout mix design. ...................................................................3

Table 2-1. Fresh property characterization, test methods, and bases. .............................................6

Table 3-1. Ingredients used to prepare samples of equipment grouts. .............................................8

Table 4-1. Cooling coil grout screening tests...............................................................................................12

Table 4-2. Fly ash modified cooling coil mixes....................................................................................14

Table 4-3. Summary of thermal properties for representative mixes............................................17 


\section{LIST OF FIGURES}

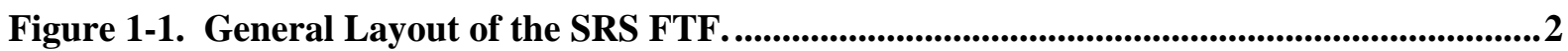

Figure 1-2. (a) ChemGrout ${ }^{\mathrm{TM}}$ GC-500-DH skid mounted equipment used in the full-scale cooling coil grout mixing and placement demonstration and (b) view of paddle blades inside mixing tank.

Figure 3-1. Examples of (a) paddle mixing and (b) colloidal (shear) mixing used to prepare samples for grout formulation development.................................................................................8

Figure 4-1. ASTM C939 flows for different water amounts to cooling coil grout........................12

Figure 4-2. Calorimeter temperatures for SRR coiling coil grout (MF816-1H)............................13

Figure 4-3. Calorimeter results for $1 / 2$ of the Masterflow ${ }^{\circledR}$ substituted with fly ash (Mix 23H)...15

Figure 4-4. Calorimeter results for $5 / 8$ of the MasterFlow ${ }^{\circledR}$ substituted with

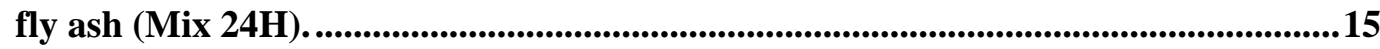

Figure 4-5. Calorimeter temperatures for $3 / 4$ of the Masterflow ${ }^{\circledR}$ substituted with fly ash........16 


\section{LIST OF ABBREVIATIONS}

$\begin{array}{ll}\text { ADMP } & \text { Advance Design Mixer Pump } \\ \text { ASTM } & \text { American Society for Testing and Materials } \\ \text { cyd } & \text { centimeter } \\ \text { DOE } & \text { cubic yard } \\ \text { Eh } & \text { United States Department of Energy } \\ \text { FTF } & \text { Oxidation - reduction potential (volts or milli volts) } \\ \text { GSA } & \text { F-Area Tank Farm } \\ \text { HLW } & \text { General Separation Area } \\ \text { K sat } & \text { High Level Waste } \\ \text { lbs } & \text { Saturated hydraulic conductivity (for water at 20 }{ }^{\circ} \text { C) } \\ \text { PA } & \text { Pounds } \\ \text { pH } & \text { Performance Assessment } \\ \text { psi } & \text { Negative logarithm of the hydrogen ion activity in solution } \\ \text { QA } & \text { Pounds per square inch } \\ \text { SRNL } & \text { Quality Assurance } \\ \text { SRNS } & \text { Savannah River National Laboratory } \\ \text { SRR } & \text { Savannah River Nuclear Solutions, LLC } \\ \text { SRS } & \text { Savannah River Remediation, LLC } \\ \text { TTQAP } & \text { Savannah River Site } \\ \text { TTR } & \text { Task Technical and Quality Assurance Plan } \\ & \text { Technical Task Request }\end{array}$




\subsection{INTRODUCTION}

The United States Department of Energy (US DOE) intends to remove Tanks 18-F and 19-F at the Savannah River Site (SRS) from service. The high-level waste (HLW) tanks have been isolated from the F-area Tank Farm (FTF) facilities and will be filled with cementitious grout for the purpose of: 1) physically stabilizing the empty volumes in the tanks, 2) limiting / eliminating vertical pathways from the surface to residual waste on the bottom of the tanks, 3) providing an intruder barrier, and 4) providing an alkaline, chemical reducing environment within the closure boundary to limit solubility of residual radionuclides [1].

Bulk waste and heel waste removal equipment will remain in Tanks 18-F and 19-F when the tanks are closed. This equipment includes: mixer pumps, transfer pumps, transfer jets, equipment support masts, sampling masts and dip tube assemblies. The current Tank 18-F and 19-F closure strategy is to grout the internal void spaces in this equipment to eliminate fast vertical pathways and slow water infiltration to the residual material on the tank floor [2].

This report documents the results of laboratory testing performed to identify a grout formulation for filling the abandoned equipment in Tanks 18-F and 19-F.

\subsection{Objective}

The objective of this work was to formulate a flowable grout for filling internal voids of equipment that will remain in Tanks $18-\mathrm{F}$ and $19-\mathrm{F}$ during the final closures. This work was requested by V. A. Chander, Tank Farm Closure Engineering, in HLW-TTR-2011-008 [3]. The scope for this task is provided in the Task Technical and Quality Assurance Plan (TTQAP), SRNL-RP-2011-00587 [4].

The specific objectives of this task were to:

- Prepare and evaluate the SRR cooling coil grout identified in WSRC-STI-2008-00298 [5] per the TTR for this work [3]. The cooling coil grout is a mixture of BASF MasterFlow ${ }^{\circledR} 816$ cable grout (67.67 wt. \%), Grade 100 ground granulated blast furnace slag (7.52 wt. \%) and water $(24.81$ wt. \%).

- Identify equipment grout placement and performance properties.

- Design up to 2 additional grout systems for filling the Tank 18-F and Tank 19-F equipment.

- Prepare samples of candidate grouts and measure fresh properties, thermal properties and cured properties.

- Recommend a grout for the Tier 1A equipment fill mock up

- ADMP 4 foot high mock up

- 1 inch and 2 inch pipes

- Support procurement of materials for the Tier 1A equipment fill mock up test.

- Prepare samples of the recommended grout for hydraulic property measurements which can be used for comparison to values used in the F- Tank Farm Performance Assessment (PA).

- Document equipment fill grout data and recommendations in a report. 


\subsection{Background}

The F-Tank Farm (FTF) is located in the General Separations Area (GSA) of the Savannah River Site (SRS) and includes twenty-two waste tanks constructed between 1951 and 1976. It comprises approximately 20 acres. See Figure 1-1. The closure concept for Tank 18-F and 19-F is to fill the waste tanks with one grout formulation, a structural flowable fill which is chemically reducing and serves as an intruder barrier after closure, i.e., an All-In-One mix design [1].

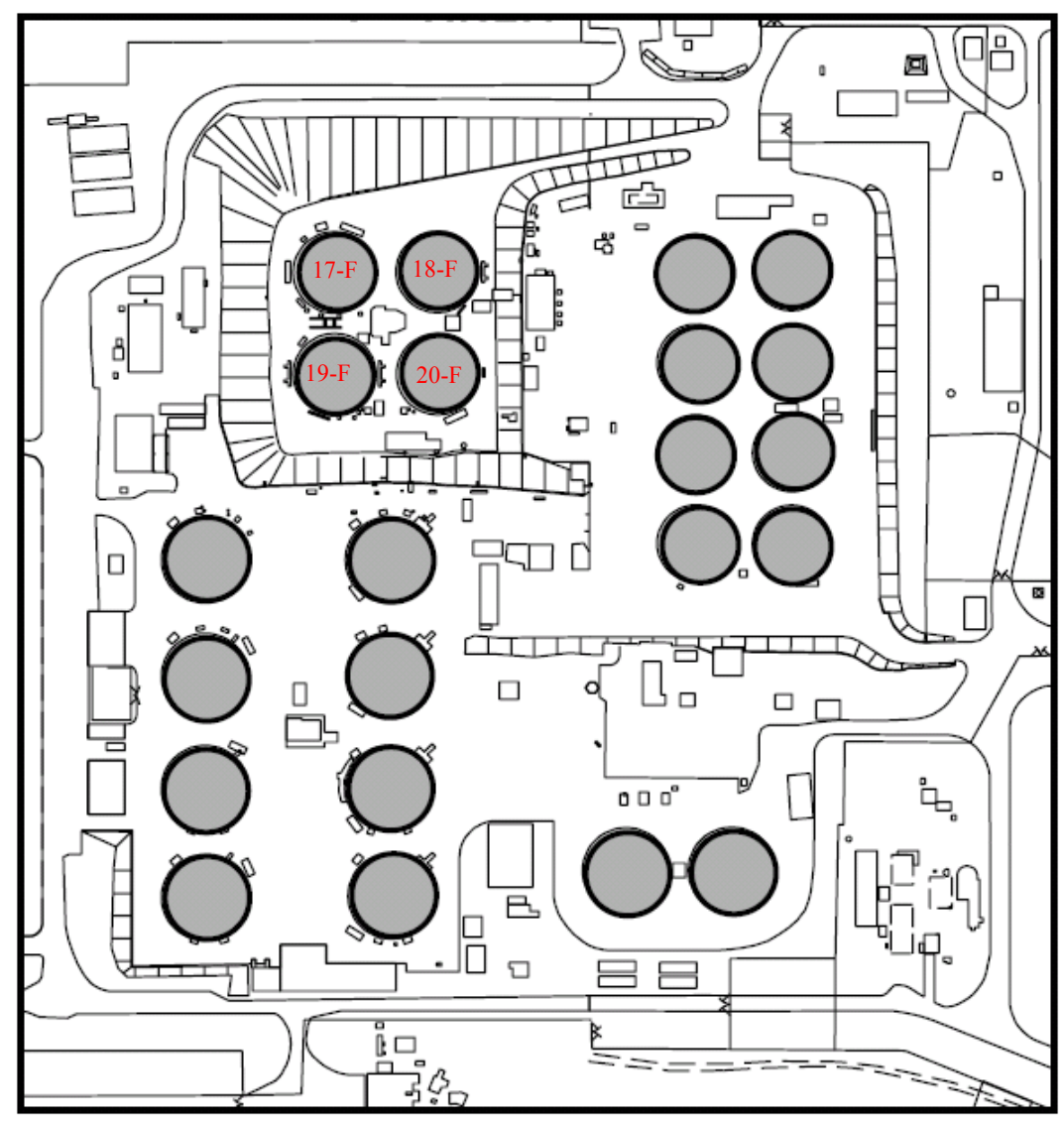

Figure 1-1. General Layout of the SRS FTF.

Several large pieces of vertically positioned equipment used to remove bulk waste and heel material from Tanks 18-F and 19-F will be entombed during the tank closure process [1]. The equipment is supported in the tank riser and by structural steel above the riser. Void space within the equipment will be filled with grout to the extent practical as the tanks are filled will a structural fill grout. Lists of equipment that will be filled with grout are provided in Tables 1-1 and 1-2.

The Advanced Design Mixer Pump (ADMP) is the largest pump and has the greatest internal void volume. The ADMP is unique in that the configuration provides a single flow path for filling and venting a multiple chamber, 55 feet length support column. Openings in the plates separating the chambers have small diameters (1 inch, minimum). The configurations and estimated grout volumes for filling ancillary equipment are summarized elsewhere [6] 
Table 1-1. Equipment suspended at tank risers and remaining in Tank 18-F.

\begin{tabular}{|l|c|c|}
\hline Equipment & Riser & Associated Pipe Sizes (inch) \\
\hline ADMP & Center & $16,18,1.5$ \\
\hline Telescoping Transfer Pump (TTP) & West & 10 \\
\hline Two Standard Slurry Pumps & East, Northwest & 16 \\
\hline Evaporator Feed Pump & Southeast & $2.5,1.5,0.75$ \\
\hline Sampling Mast & Northeast & $1.5,1.0$ \\
\hline
\end{tabular}

Table 1-2. Equipment suspended at tank risers and remaining in Tank 19-F.

\begin{tabular}{|l|c|c|}
\hline Equipment & Riser & Associated Pipe Sizes (inch) \\
\hline Telescoping Transfer Jet (TTJ) & Northwest & 3 \\
\hline Thermowell & Northeast & 1 \\
\hline Dip Tube Assembly & Northwest & 0.75 \\
\hline 3 Flygt Mixer Masts & East, West, and Southwest & $\begin{array}{c}\text { Support mast was filled } \\
\text { during fabrication [7] }\end{array}$ \\
\hline
\end{tabular}

\subsection{Previous SRS Experience with Equipment and Pipe Grouting}

SRS has limited experience with equipment and pipe filling. In 2010, two reactor vessels were filled with specially designed grouts. One of the reactor vessels contained 432 universal sleeve housings and several other obstructions which greatly restricted grout flow. A special flowable, self-leveling, zero bleed grout was designed by SRNL personnel and placed by a Gibson's Pressure Grouting Service, Inc., Smyrna GA. This material was pumped to the top of the reactor vessel and discharged into the vented reactor vessel [8].

In 2008, research was conducted to develop a grout formulation and placement strategy for filling cooling coils in HLW tanks. This research was performed in 2 phases. The first phase focused on identifying and testing mix formulations (mix designs) with performance properties suitable for filling the cooling coil piping system. The second phase consisted of selecting a mix from phase 1 testing to demonstrate scale up mixing and grout placement in cooling coil configurations representative of the minimum boundary conditions in SRS HLW tanks.

The mix design that met the processing and performance requirements for filling cooling coils ( 2 inch schedule 40 piping) and selected for full scale cooling coil grout fill demonstrations is provided in Table 1-3. The composition of the dry components of the recommended grout (by mass) was $10 \%$ grade 100 blast furnace slag and $90 \%$ Masterflow ${ }^{\circledR} 816$ cable grout. The premix of powders was blended into water at a water to premix mass ratio of 0.33 . The resulting mix provided a fill that was pumpable, had good workability, no bleed or segregation, low shrinkage, good strength, low saturated hydraulic conductivity and met the heat limit provided the recommendations for heat dissipation during full scale implementation were followed. The details covering the Phase 1 grout formulation development are documented in a report [9].

Table 1-3. SRR tank closure cooling coil grout mix design.

\begin{tabular}{|l|c|c|}
\hline Component & Mass fraction [5, 9] & lbs / cu ft \\
\hline Masterflow ${ }^{\circledR} 816$ cable grout & 0.6767 & $\sim 84.5$ \\
\hline Slag Cement, Grade 100 & 0.0752 & $\sim 9.39$ \\
\hline Water & 0.2481 & $\sim 31$ \\
\hline Water : Powder (by weight) & \multicolumn{2}{|c|}{0.33} \\
\hline
\end{tabular}


The full scale cooling coil grout mixing consisted of batching grout in a commercial grout plant and filling vertical and horizontal cooling coil configurations [5]. A skid mounted ChemGrout ${ }^{\mathrm{TM}}$ GC500DH grout mixer/pumping unit with two 70 gallon mixing tanks, a 15 gallon holding hopper and an open throat progressive cavity pump was used in the test. See Figure 1-2(a). Each 70 gallon mixing tank had a variable speed agitator driven by hydraulic fluid that turned a paddle with 2 blades. See Figure 1-2(b). A water tank, not shown, was also part of the set up and used for metering a specified volume of water into each mixing tank. The ChemGrout ${ }^{\mathrm{TM}}$ mixer in Figure 1-2 is currently owned by SRR Tank Closure Operations and was initially considered for preparing the Tank 18-F and 19-F equipment fill grout.

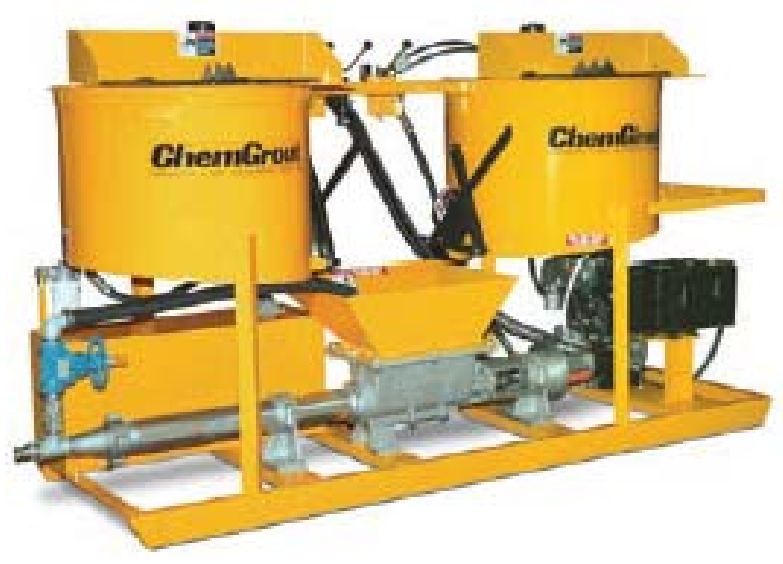

(a)

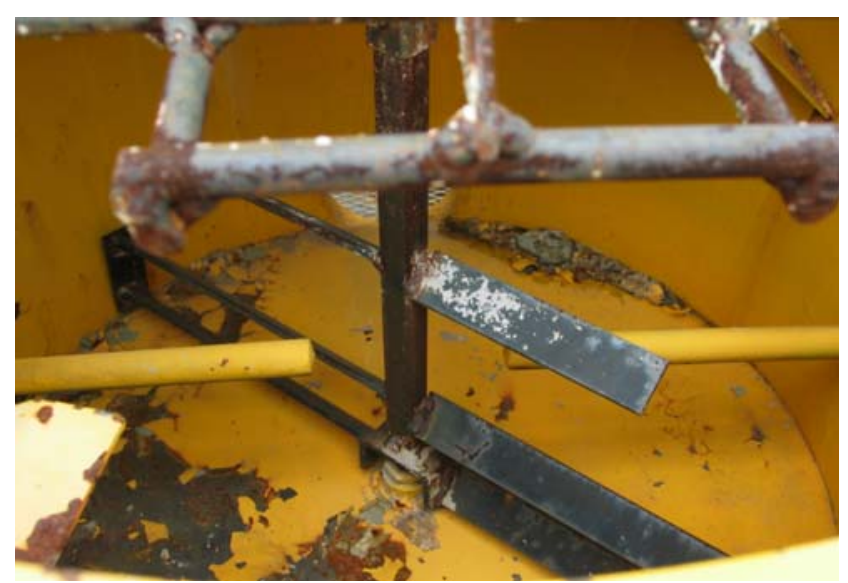

(b)

Figure 1-2. (a) ChemGrout ${ }^{\mathrm{TM}}$ GC-500-DH skid mounted equipment used in the full-scale cooling coil grout mixing and placement demonstration and (b) view of paddle blades inside mixing tank. 


\subsection{EQUIPMENT GROUT REQUIREMENTS}

The requirement for filling abandoned equipment is that the equipment should be filled to the extent practical $[1,2,3]$. The general performance and material requirements for the equipment fill grout material are listed below $[2,3]$ :

- The grout must be alkaline and chemically reducing, i.e., contain slag. The basis for this requirement is that the cooling coil grout that was selected as the base case contained slag and a Portland cement-based binder.

- Flowable enough to fill equipment voids

- Form a solid material upon curing

- Resist water infiltration, i.e., minimize arduous vertical pathways to minimize the amount of infiltrating water that can contact residual waste at the bottom of the tank.

General grout material requirements (not specified in the TTR and closure module) include:

- Pumpable slurry

- Compatible with the materials of construction of the equipment.

- Does not result in reactions that over pressurize the equipment during or after filling.

- Homogeneous material.

The FTF PA does not speak to the equipment or the equipment fill grout in the discretization of the model. Consequently no equipment fill grout parameters are required to satisfy the PA process. However, a series of experimental test protocols for evaluating and comparing the trial mixes were developed for the equipment fill grouts. These protocols provide physical and hydraulic property data to evaluate the trial mixes.

\subsection{Equipment Grout Test Methods and Screening Criteria}

A list of test methods used to characterize the equipment grout slurries are provided in Table 2-1. Test methods, target values, and the bases for these values are included in Table 2-1. A list of test methods for properties of cured equipment grouts is provided in Table 2-2. 
Table 2-1. Fresh property characterization, test methods, and bases.

\begin{tabular}{|c|c|c|c|}
\hline Property & Design Target & Test & Basis \\
\hline \multicolumn{4}{|l|}{ Fresh Slurry Properties } \\
\hline Initial Flow Cone (s) & $<20$ & ASTM C939 & SRNL Reactor ISD experience \\
\hline Initial Flow (inches) & $\geq 10.5$ & ASTM D6103 & SRNL Reactor ISD experience \\
\hline $\begin{array}{l}\text { Static Flow performed after } \\
30 \text { minutes under static } \\
\text { conditions (inches) }\end{array}$ & $\geq 8$ & $\begin{array}{l}\text { SRNL Modified } \\
\text { ASTM D6103 }\end{array}$ & SRNL Reactor ISD experience \\
\hline Air Content (vol. \%) & $\leq 8$ & ASTM C231 & SRNL Reactor ISD experience \\
\hline Set Time (hr.) & $<24 \mathrm{hr}$ & $\begin{array}{c}\text { Modified } \\
\text { ASTM C403 or } \\
\text { SRNL UPV method }\end{array}$ & SRNL Reactor ISD experience \\
\hline $\begin{array}{l}\text { Bleed water after } 24 \mathrm{hr} \\
\text { (vol. \%) }\end{array}$ & 0 & ASTM C232 & $\begin{array}{l}\text { Homogeneous material, no } \\
\text { segregation }\end{array}$ \\
\hline $\begin{array}{l}\text { Wet Unit Weight } \\
\text { (lbs/cu ft) }\end{array}$ & $\begin{array}{l}\text { Value required } \\
\text { for QC }\end{array}$ & ASTM C138 & $\begin{array}{l}\text { Unit weight depends on the } \\
\text { mix design. Therefore it } \\
\text { should not be a requirement. }\end{array}$ \\
\hline $\begin{array}{l}\text { Maximum temperature } \\
\text { during curing }\left({ }^{\circ} \mathrm{C}\right)\end{array}$ & 65 & $\begin{array}{l}\text { Calculated based on } \\
\text { SRNL adiabatic } \\
\text { calorimeter data, } \\
\text { specific heat and } \\
\text { thermal conductivity. }\end{array}$ & $\begin{array}{l}\text { SRNL Reactor ISD experience } \\
\text { and Portland cement based } \\
\text { material properties }\end{array}$ \\
\hline Specific Heat & \multirow[t]{2}{*}{ None } & \multirow[t]{2}{*}{ SRNL / EDL Method } & \multirow{2}{*}{$\begin{array}{l}\text { Values used in adiabatic } \\
\text { temperature rise calculation and } \\
\text { in thermal transient modeling }\end{array}$} \\
\hline Thermal Conductivity & & & \\
\hline Slurry pH & $\geq 12.4$ & $\begin{array}{c}\text { Portland cement } \\
\text { based grout } \\
\text { i.e., Masterflow }{ }^{\circledR} 816 \\
\text { Base Case }\end{array}$ & $\begin{array}{l}\quad 2007 \text { FTF PA* } \\
\text { TTR Cooling Coil Base Case } \\
\text { Grout } \\
\text { High alkalinity is consistent } \\
\text { with the waste tank operating } \\
\text { conditions and does not require } \\
\text { further analysis for tank } \\
\text { corrosion and solubility of } \\
\text { residuals. }\end{array}$ \\
\hline $\begin{array}{l}\text { Maximum Slurry Particle } \\
\text { Size (in.) }\end{array}$ & $<0.2$ inch & Screen & $\begin{array}{l}\text { Limited by piping and openings } \\
\geq 1 \text { inch ID in equipment } \\
\text { (minimize potential for } \\
\text { bridging) }\end{array}$ \\
\hline $\begin{array}{l}\text { Static Working Time } \\
\text { (screening) }\end{array}$ & $>60$ minutes & & $\begin{array}{l}\text { Based on time estimated to fill } \\
\text { the ADMP at }<5 \text { gpm }\end{array}$ \\
\hline $\begin{array}{l}\text { Dynamic Working Time } \\
\text { (screening) }\end{array}$ & $>60$ minutes & & $\begin{array}{l}\text { Based on time estimated to fill } \\
\text { the ADMP at }<5 \text { gpm and } \\
\text { estimated batch size }\end{array}$ \\
\hline
\end{tabular}

* Equal to or more conservative than values in 2007 Material Property Data Package for the FTF PA [10].

\footnotetext{
${ }^{3}$ The value in the TTR, $132 \mathrm{lbs} / \mathrm{cyd}$, assumed a mix design and mix variability other than the mix recommended and the allowable variability [3].
} 
Table 2-2. Cured property test methods, target values and bases.

\begin{tabular}{|c|c|c|c|}
\hline Property & Target Values & Test & Basis \\
\hline \multicolumn{4}{|l|}{ Cured Properties } \\
\hline Compressive Strength (psi) & $\begin{array}{c}\geq 2000 \text { at } 28 \text { days } \\
(13.8 \mathrm{MPa})\end{array}$ & ASTM C39 & $\begin{array}{l}\text { Information only } \\
\text { Same as bulk fill }\end{array}$ \\
\hline Effective Porosity (vol. \%) & $\begin{array}{l}\text { Measure for input } \\
\text { to closure PA }\end{array}$ & $\begin{array}{c}\text { Modified ASTM } \\
\text { C642 }\end{array}$ & Information only \\
\hline Dry Bulk Density (g/cm3) & $\begin{array}{l}\text { Measure for input } \\
\text { to closure PA }\end{array}$ & $\begin{array}{c}\text { Modified ASTM } \\
\text { C642 }\end{array}$ & Information only \\
\hline $\begin{array}{l}\text { Particle Density (g/cm3) } \\
\text { (Averaged particle density) }\end{array}$ & $\begin{array}{l}\text { Calculate for input } \\
\text { to closure PA }\end{array}$ & $\begin{array}{l}\text { Calculated from } \\
\text { porosity and dry } \\
\text { bulk density }\end{array}$ & Information only \\
\hline $\begin{array}{l}\text { Dimensional Stability } \\
\text { Shrinkage }\end{array}$ & TBD & TBD & Information only \\
\hline $\begin{array}{l}\text { Alkalinity of water in } \\
\text { contact with sample cured } \\
\text { for } 90 \text { days }\end{array}$ & $\begin{array}{c}\mathrm{pH} \geq 12.4 \\
\geq 75 \text { lbs Portland } \\
\text { cement /cyd }\end{array}$ & $\begin{array}{c}\mathrm{QC} \\
\geq 75 \mathrm{lb} / \text { cyd }\end{array}$ & $\begin{array}{l}\text { Information only } \\
2007 \text { FTF PA* }\end{array}$ \\
\hline Reducing Capacity & $\begin{array}{c}\mathrm{Eh} \sim-200 \text { to }-400 \mathrm{mV} \\
\quad \geq 210 \mathrm{lbs} \text { slag } / \text { cyd }\end{array}$ & $\begin{array}{l}\text { Quality Control } \\
\geq 210 \mathrm{lb} / \text { cyd }\end{array}$ & $\begin{array}{c}\text { Information only } \\
2007 \text { FTF PA* }\end{array}$ \\
\hline $\begin{array}{l}\text { Effective Diffusion } \\
\text { Coefficient }(\mathrm{De})(\mathrm{cm} 2 / \mathrm{s})\end{array}$ & $\leq 8.00 \mathrm{E}-07$ & $\begin{array}{l}\quad \mathrm{D}_{\mathrm{e}} \text { is a } \\
\text { representative } \\
\text { literature value } \\
\text { applied to all } \\
\text { soluble ions }\end{array}$ & $\begin{array}{l}\text { Information only } \\
2007 \text { FTF PA* }\end{array}$ \\
\hline $\begin{array}{l}\text { Saturated Hydraulic } \\
\text { Conductivity at } 20^{\circ} \mathrm{C}, \\
\text { average }\left(\text { Khsat@ } 20^{\circ} \mathrm{C}\right) \\
(\mathrm{cm} / \mathrm{s})\end{array}$ & $\leq 3.6 \mathrm{E}-08$ & $\begin{array}{l}\text { ASTM D } 5084 \\
\text { Method F } \\
\text { measured at } \\
\text { MACTEC }\end{array}$ & $\begin{array}{c}\text { Information only } \\
2007 \text { FTF PA* }\end{array}$ \\
\hline & & $\begin{array}{c}\text { ASTM D } 5084 \\
\text { Method C } \\
\text { measured at URS }\end{array}$ & \\
\hline Kds for selected contaminants & [11] & [11] & Information only \\
\hline \multicolumn{4}{|l|}{$\begin{array}{l}\text { Unsaturated Transport } \\
\text { Properties }\end{array}$} \\
\hline $\begin{array}{l}\text { Volumetric Moisture } \\
\text { Content versus pressure } \\
\text { (where pressure is capillary } \\
\text { head.) }\end{array}$ & $\begin{array}{c}\text { Measure for input to } \\
\text { closure PA }\end{array}$ & $\begin{array}{l}\text { ASTM D3152 } \\
\text { Test performed by } \\
\text { MACTEC }\end{array}$ & $\begin{array}{l}\text { Information only } \\
\text { Same as bulk fill }\end{array}$ \\
\hline $\begin{array}{l}\text { Volumetric Moisture } \\
\text { Content versus pressure } \\
\text { (pressure = capillary head.) } \\
\text { For } 15 \text { bar ( } 218 \text { psi) to } 45 \\
\text { bar ( } 653 \text { psi) }\end{array}$ & Same as above & $\begin{array}{l}\text { Modified ASTM } \\
\text { D3152 } \\
\text { Test performed by } \\
\text { SRNL, K. Dixon } \\
\text { and may still be } \\
\text { under } \\
\text { development. }\end{array}$ & $\begin{array}{l}\text { Information only } \\
\text { Same as bulk fill }\end{array}$ \\
\hline
\end{tabular}

\footnotetext{
* Equal to or more conservative than values in 2007 Material Property Data Package for the FTF PA [10].
} 


\subsection{EXPERIMENTAL METHODOLOGY}

\subsection{Ingredients}

Grouts tested in this study were prepared with materials obtained from local suppliers that are distributed nationwide. The Masterflow ${ }^{\circledR} 816$ cable grout was manufactured by BASF Masterbuilders, Inc. and obtained through WhiteCap Construction Supply, Martinez, GA. The Grade 100 blast furnace slag cement was manufactured by Holcim, Inc., Birmingham, AL. The Class F fly ash, which met ASTM C618 standards, was generated at the Wateree Power Plant and supplied by SEFA, Inc. Water in $\mathrm{N}$-area was used to prepare the grout mixes. The ingredients used for preparing samples are summarized in Table 3-1.

Table 3-1. Ingredients used to prepare samples of equipment grouts.

\begin{tabular}{|l|l|c|}
\hline \multicolumn{1}{|c|}{ Material } & \multicolumn{1}{|c|}{ Supplier / Address } & Phone Number \\
\hline Masterflow 816 ${ }^{\circledR}$ cable grout & $\begin{array}{l}\text { BASF Masterbuilder, Inc., } \\
\text { obtained from WhiteCap } \\
\text { Construction Supply, } \\
\text { Martinez, GA 30907 }\end{array}$ & $706-868-8683$ \\
\hline $\begin{array}{l}\text { ASTM C989 Slag cement } \\
\text { (Grade 100) }\end{array}$ & $\begin{array}{l}\text { Holcim, Inc. } \\
\text { 3235 Satellite Blvd. } \\
\text { Duluth GA 30096 }\end{array}$ & $800-292-4355$ \\
\hline $\begin{array}{l}\text { ASTM C618 Fly ash } \\
\text { (Class F) }\end{array}$ & $\begin{array}{l}\text { Wateree Power Plant, SC } \\
\text { SEFA, Inc. }\end{array}$ & $800-241-4943$ \\
\hline Process water & SRS domestic water & \\
\hline
\end{tabular}

\subsection{Sample Preparation and Test Methods}

Sample preparation and testing was performed in the SRS Civil Engineering Test Laboratory which is operated by URS, Quality and Testing Division. The laboratory is located in N-Area. Samples were prepared according to ASTM C192 and cured in a constant temperature $\left(73^{\circ} \mathrm{F} \pm 2^{\circ} \mathrm{F}\right)$ curing room at $100 \%$ relative humidity. A Hobart planetary mixer (See Figure 3-1a) and bench top

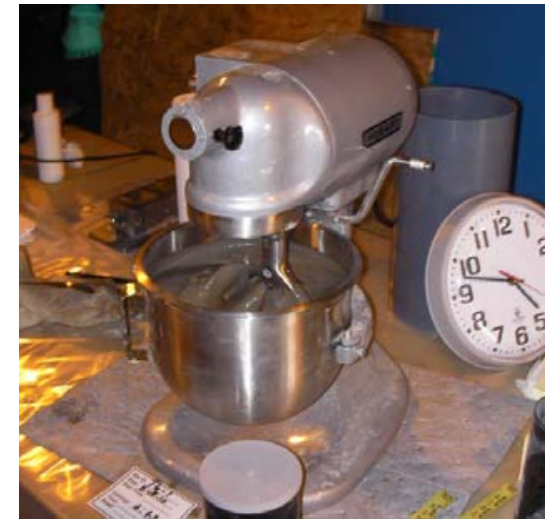

a

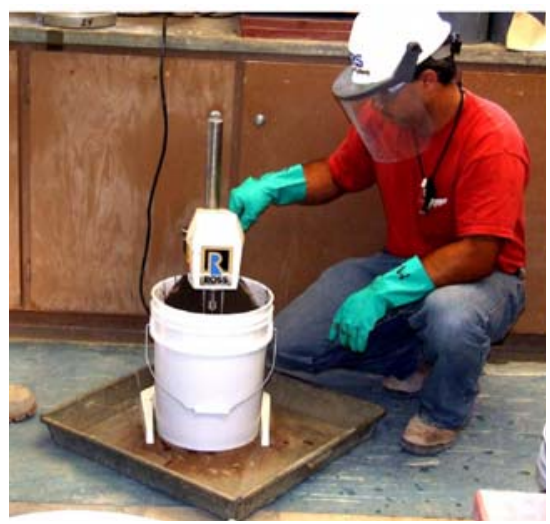

B

Figure 3-1. Examples of (a) paddle mixing and (b) colloidal (shear) mixing used to prepare samples for grout formulation development. 
laboratory mixer, Ross HSM 100-L with disintegrating head (See Figure 3-1b), were used for preparing the grout mixes. The maximum batch size for the Hobart mixer was 1/10 of a cubic foot.

The order of addition of ingredients for mixing was water and then solids. Dry solids were a powdered blend of the Masterflow ${ }^{\circledR} 816$ cable grout, slag cement and Class F fly ash, where applicable, to serve as an inert filler. The mixing time using the Hobart mixer was typically 5 minutes after all the dry ingredients were added. For the mixes that were paddle mixed and sheared, the powders were first hydrated in the paddle mixer and then sheared through the bench top laboratory mixer for 30 seconds. A stopwatch was used to assist in controlling mixing times.

The grout fluidity was determined using an ASTM flow cone and stopwatch (Method ASTM C939). The time for $1725 \mathrm{ml}$ of water to pass through an ASTM flow cone with $1 / 2$ " diameter discharge is $8.0 \pm$ 0.1 seconds. Prior to the test, water was run through the flow cone to verify the discharge rate and then the cone was allowed to drain for 1 minute before testing the grout. The discharge tube was blocked with a finger and grout put into the cone until it filled to the tip of a pointer (See Figure 3-2a).

Simultaneously, a stopwatch was started and the finger removed. Time was stopped at the first break in continuous flow from the discharge tube.

The static spread test was performed using 3" x 6" plastic cylinders which were open at both ends. These containers were placed on a 24 inch spread board and filled with grout. The cylinders were lifted (pulled) at select time intervals and the grout spread was measured in two directions and averaged (SRNL modified ASTM D6103). Cylinders were covered and weighted while waiting to be pulled.

See Figure 3-2 (b).

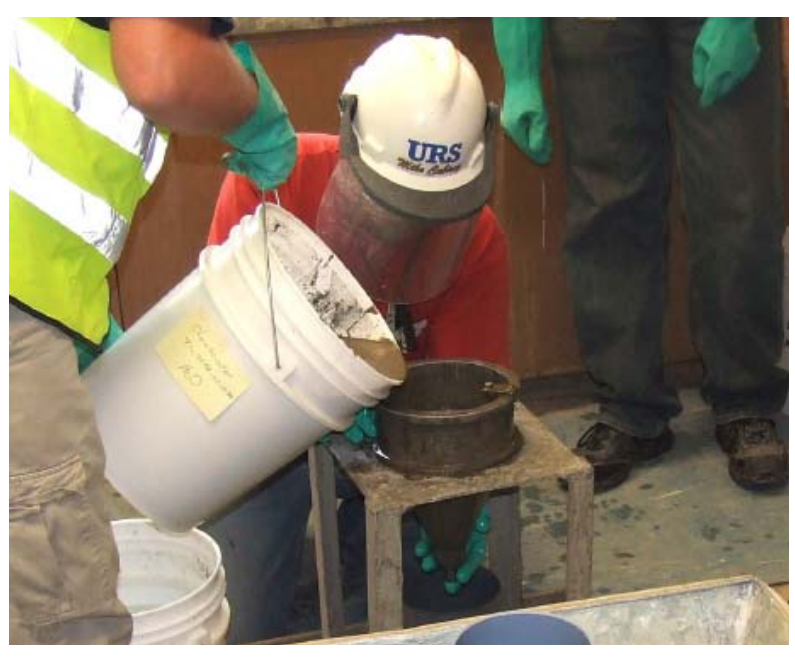

(a)

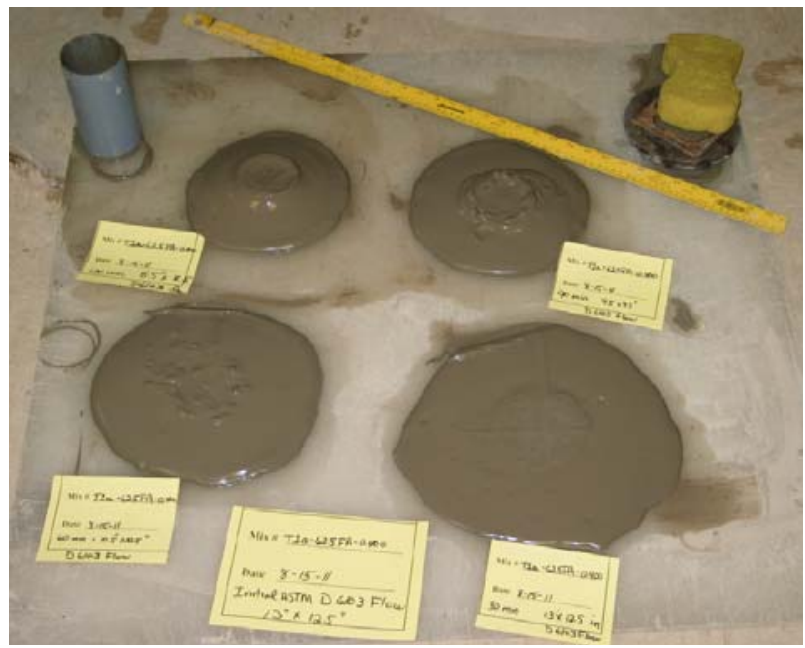

(b)

Figure 3-2. Examples of (a) ASTM C939 flow cone measurement and (b) Modified ASTM D6103 flow under initial and static conditions.

Bleed water was determined by pouring a grout sample in a cylinder, capping the cylinder and waiting 24 hours before measuring the bleed volume inside the capped cylinder (Method ASTM C232/C232M). The grout was also checked to verify it set when checking for bleed in the cylinder.

Grout set time for selected mixes was determined by the ultrasonic pulse velocity (UPV) method or approximated using adiabatic calorimeter data. Air content was checked using the apparatus in Figure 3-3a (Method ASTM C231/C231M). The pot portion was also used as the unit volume container for determining unit weights. 
Three by six inch cylinders were cast for compressive strength measurements as a function of curing times ( 7 and 28 days). Two by four inch cylinders were cast for hydraulic conductivity measurements at the URS Civil laboratory (ASTM D5084 Method C). All samples cast were cured in a controlled environment. The compression tester and a permeability cell are shown in Figure 3-3 (b) and (c), respectively.

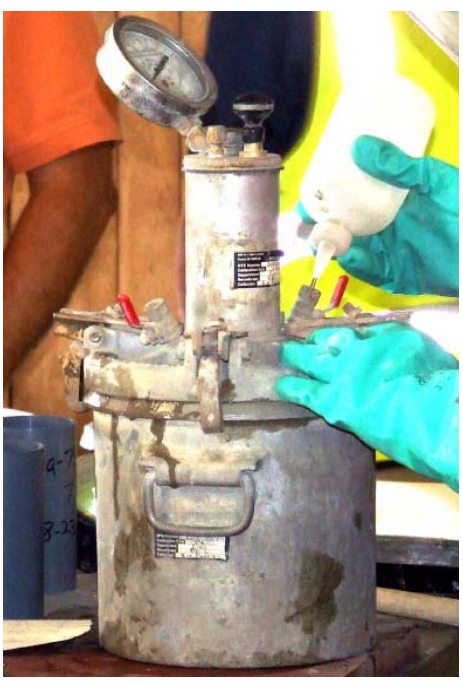

(a)

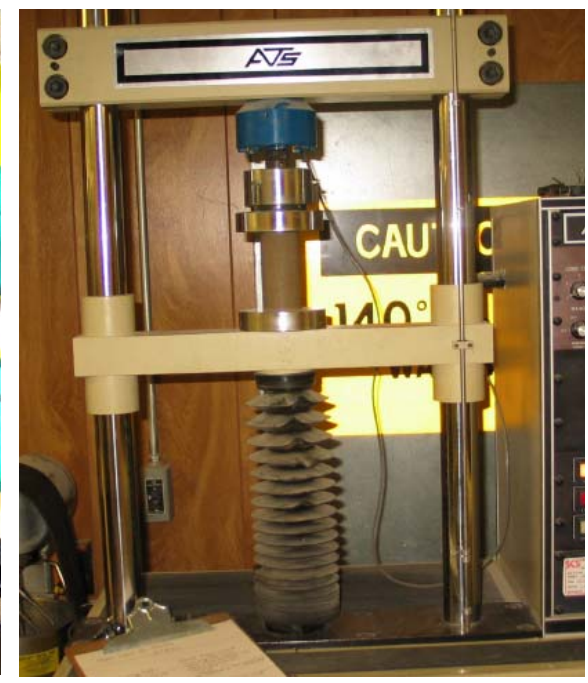

(b)

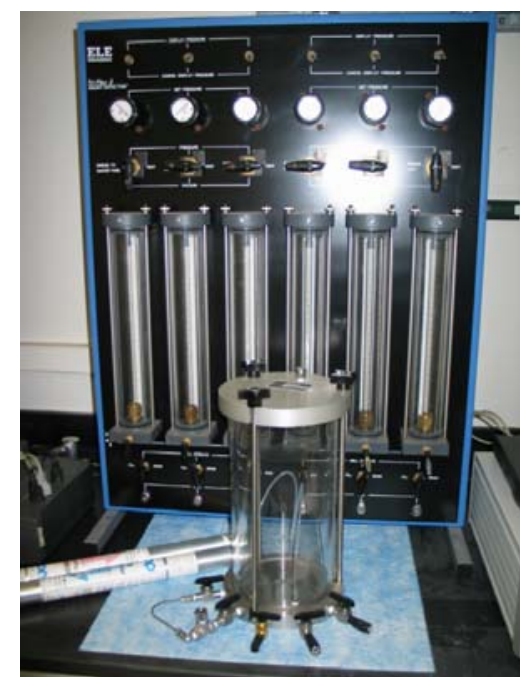

(c)

Figure 3-3. Examples of (a) ASTM C231/C231M apparatus for determining air content, (b) compression tester for determining strength, and (c) hydraulic conductivity test apparatus and sample cell.

Adiabatic calorimetry was used to measure heats of hydration and adiabatic temperature increases for the different grout compositions by the SRNL Engineering Development Laboratory (EDL). The set up consisted of a well-insulated calorimeter fitted with a stirrer and thermocouples (See Figure 3-4). The protocol followed is documented in a previous report [12].

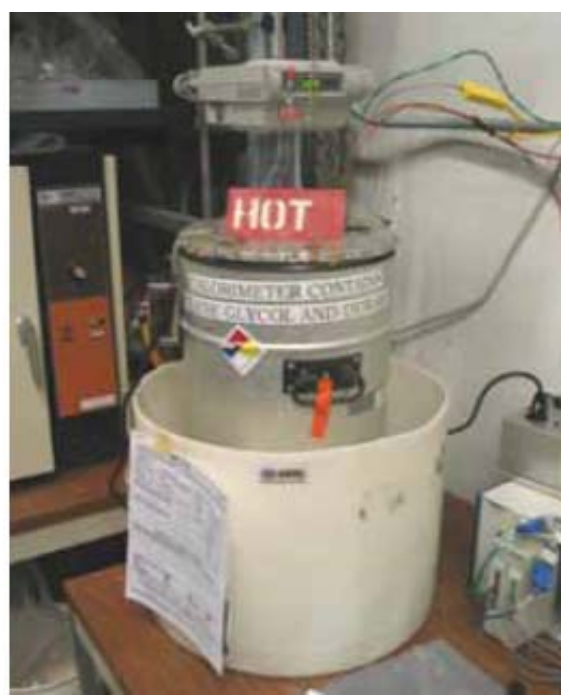

Figure 3-4. SRNL adiabatic calorimeter used to measure grout temperature during hydration. 


\subsection{RESULTS}

Results for flowable equipment fill concepts containing MasterFlow ${ }^{\circledR} 816$ cable grout, blast furnace slag and fly ash are provided in this report. Mix development and testing was carried out in three (3) phases.

- Phase 1 consisted of preparing the SRR cooling coil grout formulation specified in WSRC-STI2008-00298 and evaluating whether the cementitious material is suitable for filling ancillary equipment in the Tank 18-F and 19-F closure boundaries.

- Phase 2 consisted of formulating up to 2 additional mix designs for filling ancillary equipment using Masterflow ${ }^{\circledR} 816$ cable grout and slag as components in the grout formulation and based on the results of Phase 1 testing

- Phase 3 focused on water extended grout formulations, if necessary, and was based on the results of phase 1 and phase 2 testing.

An initial series of fly ash only slurries was prepared to provide SRR engineering with three nonreactive slurry formulations to support the SRR mock up testing. These mixes are not reported in this document.

\subsection{Phase 1: Cooling Coil Grout Base Case}

Per the TTR, the cooling coil grout formulation was selected as the base case. This grout was a mixture of Masterflow ${ }^{\circledR} 816$ cable grout (67.67 wt. \%), Grade 100 slag (7.52 wt. \%) and water (24.81 wt. \%). Mix proportions for the base case (Mix 13) along with fresh and cured properties are provided in Table 4-1. The batch size prepared in the laboratory was $4000 \mathrm{~g}$. The rheology of the base case grout mixed in a Hobart mixer for 5 minutes was 32 seconds per the ASTM C939 flow cone method. Small increases in the amount of water added to the base case formulation resulted in measurable changes in the rheology. (Compare Mix 14 to 14a, b, and c.) Results are listed in Table 4-1 and plotted in Figure 4-1.

The amount of mechanical energy imparted to the base case slurry (water to cementitious material = 0.33 ) also impacted the slurry rheology. An $8000 \mathrm{~g}$ batch of the base case cooling coil grout (Mix 15) was prepared in the Hobart mixer and mixed for 5 minutes. The flow cone rheology was 56 seconds. Mixing an additional 5 minutes (total of 10 minutes) in the Hobart planetary mixer produced a slurry with a rheology of 49 seconds (Mix 15). Remixing this slurry in a colloidal mixer for 30 seconds produced a slurry with an 18 second flow cone rheology (Mix $15 \mathrm{w} /$ colloidal mixing). Results are provided in Table 4-1.

Based on these results, subsequent mixes were prepared with a combination of paddle mixing to wet the solids and a short period of colloidal/shear mixing.

The base case cooling coil mix contains a large amount of reactive material as indicated by the high 7 day strengths (5530 psi) and the observation that steam vents formed on the surface of this grout cast into a 55 gallon drum filled as part of the full-scale demonstration performed by SRNL [5].

Consequently, adiabatic calorimetery was one of the first measurements made on the base case cooling coil mix (Mix 13). The calorimeter temperatures versus time are provided in Figure 4-2. The base case cooling coil grout formulation exceeded $100^{\circ} \mathrm{C}$ for starting materials at $20.4^{\circ} \mathrm{C}$. The grout temperature rapidly increased after an induction period of about 5 hours before peaking at $104.1^{\circ} \mathrm{C}$. (Under sealed conditions, where steam is not able to escape, the maximum temperature would have been higher.) 
The specific heat and thermal conductivity for the cooling coil grout formulation were also determined and are $1428 \mathrm{~J} / \mathrm{kg}-\mathrm{K}$ and $0.80 \mathrm{~W} / \mathrm{m}-\mathrm{K}$, respectively. The compressive strength after 7 days of curing was measured at $5530 \mathrm{psi}$. The samples did not bleed or segregate.

Table 4-1. Cooling coil grout screening tests.

\begin{tabular}{|c|c|c|c|c|c|c|}
\hline & \multicolumn{6}{|c|}{ Paddle mixed in Hobart planetary mixer on middle setting } \\
\hline Component (wt.\%) & $\begin{array}{c}\text { Base } \\
\text { Case 13 } \\
\end{array}$ & $\begin{array}{c}\text { Base } \\
\text { Case 14 } \\
\end{array}$ & 14a & $14 \mathbf{b}$ & 14c & $\begin{array}{c}\text { Base } \\
\text { Case 15 } \\
\end{array}$ \\
\hline Masterflow $^{\circledR} 816$ & 67.67 & 67.67 & 67.33 & 67 & 66.67 & 67.67 \\
\hline Slag, Grade 100 & 7.52 & 7.52 & 7.48 & 7.46 & 7.41 & 7.52 \\
\hline Water & 24.81 & 24.81 & 25.18 & 25.55 & 25.92 & 24.81 \\
\hline $\mathrm{W} / \mathrm{cm}_{\text {total }}$ & 0.33 & 0.33 & 0.337 & 0.343 & 0.35 & 0.33 \\
\hline \multicolumn{7}{|l|}{ Fresh Properties } \\
\hline $\begin{array}{l}\text { ASTM C939 flow cone (s) } \\
\text { after paddle mixing } 5 \text { min. }\end{array}$ & 32 & 31 & 26 & 22.5 & 20 & 56 \\
\hline $\begin{array}{l}\text { ASTM C939 flow cone (s) after } \\
\text { paddle mixing } 10 \text { min. }\end{array}$ & NM & NM & NM & NM & NM & 49 \\
\hline $\begin{array}{l}\text { ASTM C939 flow cone (s), after } \\
\text { paddle mixing } 10 \mathrm{~min} \text {. and } \\
\text { shearing } 30 \mathrm{~s}\end{array}$ & NM & NM & NM & NM & NM & 18 \\
\hline Bleed $(\mathrm{ml})$ & 0 & 0 & 0 & 0 & 0 & 0 \\
\hline \multicolumn{7}{|l|}{ Cured Properties } \\
\hline Compressive Strength (psi) & $\begin{array}{c}5530 \\
\text { (7 day) }\end{array}$ & NM & NM & NM & NM & NM \\
\hline $\begin{array}{l}\text { Saturated hydraulic } \\
\text { conductivity, } \mathrm{k}_{\text {hsat } @ 20 \mathrm{C}}(\mathrm{cm} / \mathrm{s})\end{array}$ & $3.2 \mathrm{E}-09$ & NM & NM & NM & NM & NM \\
\hline $\begin{array}{l}\text { Adiabatic Temperature Rise } \\
\left({ }^{\circ} \mathrm{C}\right)\end{array}$ & $\sim 117$ & NM & NM & NM & NM & NM \\
\hline $\begin{array}{l}\text { Maximum calorimeter } \\
\text { temperature for starting } \\
\text { temperature }\left({ }^{\circ} \mathrm{C}\right)\end{array}$ & $\begin{array}{l}\mathrm{T}_{\mathrm{i}}=20.4 \\
\mathrm{~T}_{\mathrm{f}}=104.1 \\
(\mathrm{Mix} 1 \mathrm{H})\end{array}$ & NM & NM & NM & NM & NM \\
\hline
\end{tabular}

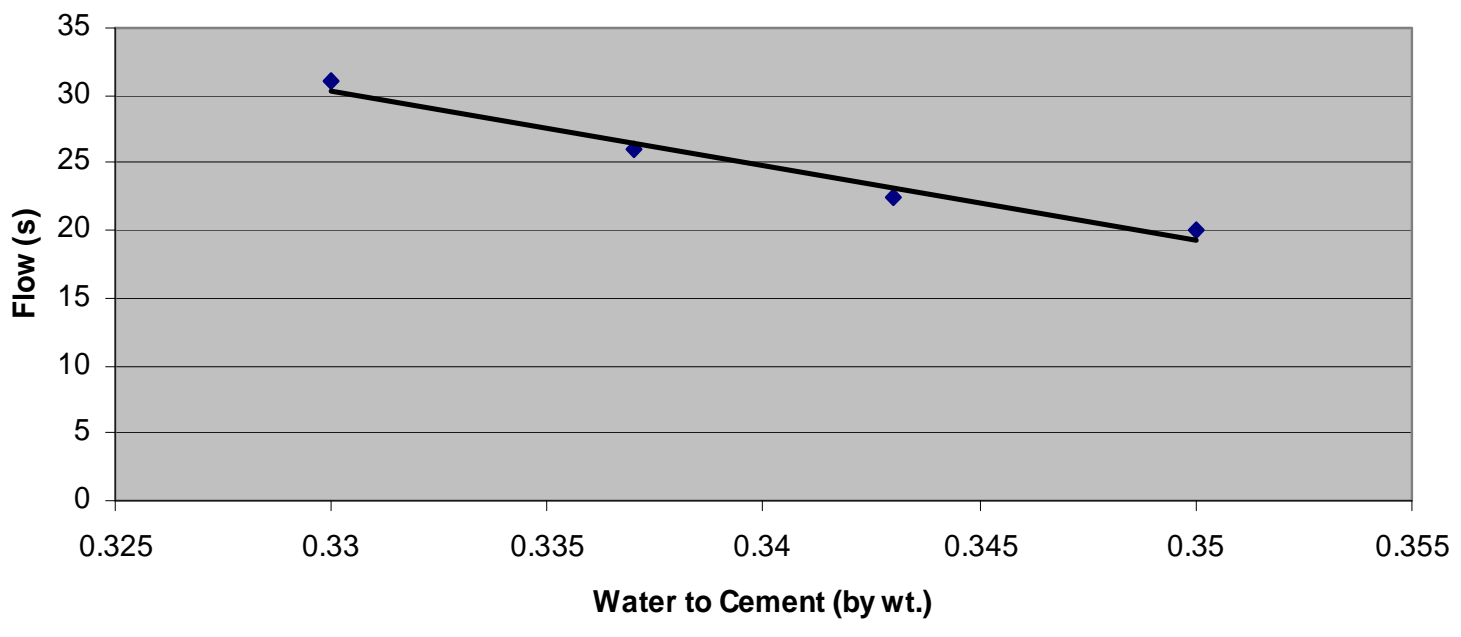

Figure 4-1. ASTM C939 flows for different water amounts to cooling coil grout. 
SRNL-STI-2011-00592

Revision 0

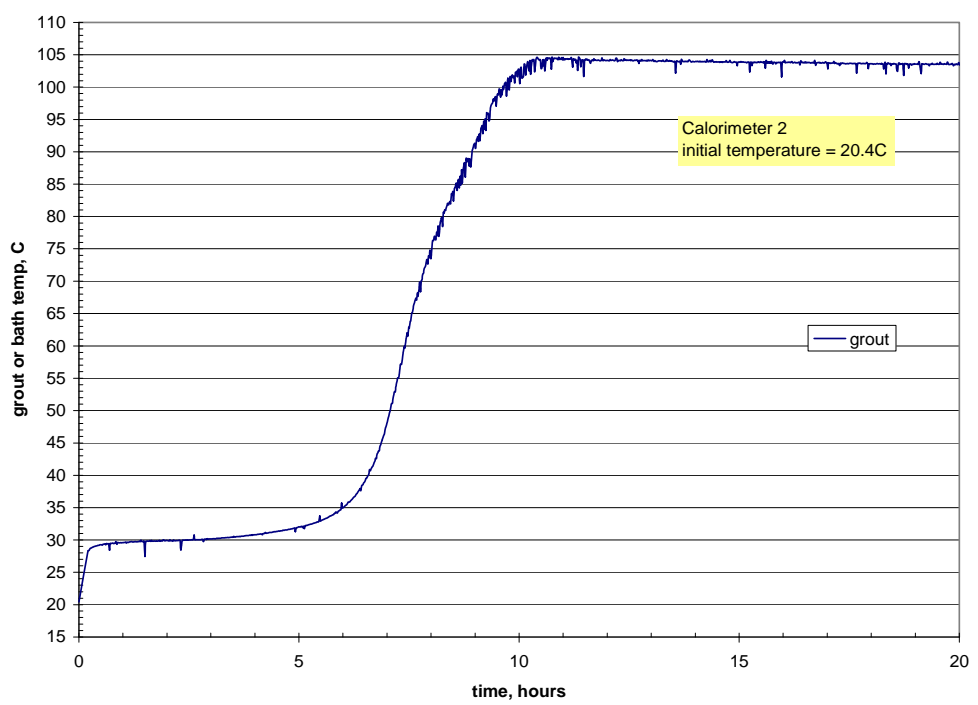

Figure 4-2. Calorimeter temperatures for SRR coiling coil grout (MF816-1H).

\subsection{Phase 2: Fly Ash Modified Cooling Coil Mixes}

The heat of reaction measured for the SRR cooling coil grout, which was the base case mix for filling ancillary equipment, was deemed to high $\left(>100^{\circ} \mathrm{C}\right)$ for Tanks $18-\mathrm{F}$ and 19-F. Consequently, the base case required modification for the equipment fill application. The modification consisted of dilution with a readily available relatively inert material, Class F fly ash.

25 and 50 Weight Percent Fly Ash Substitution: Class F fly ash was substituted for $1 / 2$ and $1 / 4$ of the Masterflow ${ }^{\circledR} 816$ cable grout (Mixes 16 and 17 in Table 4-2). The amount of slag added to the cable grout and fly ash blend was $10 \%$ the weight of Masterflow ${ }^{\circledR} 816$ plus fly ash. The water to solid ratio was held at 0.33 (same as the cooling coil grout). Mixes 16 and 17 had compressive strengths $>4000$ psi after 7 days and $>9000$ psi after 28 days. The saturated hydraulic conductivity of Mix 17 was 1.6E$09 \mathrm{~cm} / \mathrm{s}$ after 28 day curing.

The adiabatic calorimeter results for Mix 23H (same as Mix 16) are plotted in Figure 4-3. The maximum temperature measured in the calorimeter was $\sim 98^{\circ} \mathrm{C}$ for an initial starting temperature of $24.1^{\circ} \mathrm{C}$, and the estimated adiabatic temperature rise was $90^{\circ} \mathrm{C}$. Again, the grout temperature rapidly increased after an induction period of about 6 hours.

The strengths for Mix 21 (same as Mix 16) after curing 7 days and 28 days were 3800 psi and 7163 psi, respectively and the saturated hydraulic conductivity at $20^{\circ} \mathrm{C}$ was $2.1 \mathrm{E}-09 \mathrm{~cm} / \mathrm{s}$. The flow cone values for Mix 21 were 17 seconds after mixing and 26 seconds after 15 minutes under static conditions. The spread per modified ASTM D6103 after a 30 minute static period was $17.75 \mathrm{inch}$. There was no bleed for this formulation.

Mixes containing higher fly ash substitutions (62.5 and 75 wt. \%) were evaluated because of the high temperature measured for the $50 \mathrm{wt}$ \% substituted mix. Mix proportions for these cases along with fresh and cured properties are provided in Table 4-2. 
Table 4-2. Fly ash modified cooling coil mixes

\begin{tabular}{|c|c|c|c|c|c|c|c|c|c|c|c|}
\hline & No fly ash & $1 / 4$ Fly Ash & \multicolumn{3}{|c|}{$1 / 2$ Fly Ash Substitution } & \multicolumn{3}{|c|}{ 5/8 Fly Ash Substitution } & \multicolumn{3}{|c|}{ 3/4 Fly Ash Substitution } \\
\hline Ingredient (wt.\%) & 18 & 17 & 16 & 22 & $21 \& 23 \mathrm{H}$ & $24 \& 24 \mathrm{H}$ & $\begin{array}{l}\text { T1a- } \\
62.5 \mathrm{FA}- \\
0.400 \\
\end{array}$ & $\begin{array}{l}\text { T1a- } \\
62.5 \mathrm{FA}- \\
1 \mathrm{C}-0.425 \\
\end{array}$ & 19 & $25 \& 25 H$ & $\begin{array}{l}\text { T1a-75FA- } \\
1 \mathrm{C}-0.400\end{array}$ \\
\hline Masterflow ${ }^{\circledR} 816$ & 68.35 & 51.26 & 34.18 & 33.42 & 34.18 & 25.40 & 24.35 & 23.92 & 17.09 & 16.71 & 16.25 \\
\hline Slag Cement, Grade 100 & 6.84 & 6.84 & 6.84 & 6.68 & 6.84 & 6.68 & 6.5 & 6.36 & 6.84 & 6.68 & 6.49 \\
\hline $\begin{array}{l}\text { Fly Ash, Class F, } \\
\text { ASTM C618 }\end{array}$ & 0 & 17.09 & 34.18 & 33.42 & 34.18 & 41.44 & 40.59 & 39.89 & 51.26 & 50.13 & 48.69 \\
\hline Domestic Water & 24.81 & 24.81 & 24.81 & 26.47 & 24.81 & 26.47 & 28.57 & 29.83 & 24.81 & 26.47 & 28.58 \\
\hline $\mathrm{W} / \mathrm{cm}_{\text {total }}$ & 0.33 & 0.33 & 0.33 & 0.36 & 0.33 & 0.36 & 0.40 & 0.425 & 0.33 & 0.36 & 0.40 \\
\hline \multicolumn{12}{|l|}{ Fresh Properties } \\
\hline $\begin{array}{l}\text { ASTM C939 Flow Cone (s), } \\
\text { initial and after static period } \\
\text { (min) }\end{array}$ & NM & NM & NM & $\begin{aligned} t_{0} & =14.3 \\
t_{15} & =16.63\end{aligned}$ & $\begin{array}{l}t_{0}=17.02 \\
t_{15}=26.18\end{array}$ & NM & $t_{0}=16$ & $\mathrm{t}_{0}=14$ & NM & NM & $\mathrm{t}_{0}=19.1$ \\
\hline $\begin{array}{l}\text { Modified ASTM D-6103 } \\
\text { Spread (in.), initial and after } \\
\text { after static period (min) }\end{array}$ & & & & $t_{30}=16.0$ & $t_{30 .}=17.75$ & NM & $\begin{array}{l}\mathrm{T}_{0}=16.38 \\
\mathrm{~T}_{30}=12.75 \\
\mathrm{~T}_{60}=10.5 \\
\mathrm{~T}_{120}=10.5\end{array}$ & $\begin{array}{c}\mathrm{T}_{0}=21 \\
\mathrm{~T}_{30}=14.25 \\
\mathrm{~T}_{60}=13.38 \\
\mathrm{~T}_{90}=11.75\end{array}$ & & NM & $\begin{array}{c}\mathrm{T}_{0}=15.5 \\
\mathrm{~T}_{30}=11.63 \\
\mathrm{~T}_{60}=8.75 \\
\mathrm{~T}_{90}=8.63 \\
\mathrm{~T}_{120}=7.63\end{array}$ \\
\hline Air Content (vol.\%) & NM & NM & NM & NM & NM & NM & 2.2 & NM & NM & NM & 2.1 \\
\hline Set Time (hr.) & 6.5 & $<24$ & $<24$ & $<24$ & 6 & 7 & 6 & NM & $<24$ & 6 & $<24$ \\
\hline Bleed $(\mathrm{ml})$ & 0 & 0 & 0 & 0 & 0 & 0 & 0 & Yes & 0 & 0 & 0 \\
\hline Unit Weight (lbs/cu ft) & NM & NM & NM & NM & NM & NM & 108.5 & NM & NM & NM & 108.1 \\
\hline \multicolumn{12}{|l|}{ Cured Properties } \\
\hline \multicolumn{12}{|l|}{ Compressive Strengths (psi) } \\
\hline 5 days & 6490 & 4880 & 3300 & NM & NM & NM & NM & NM & 1100 & NM & NM \\
\hline 7 days & 8620 & 6170 & 4160 & 3114 & 3800 & 1975 & 1460 & 990 & 1190 & 1000 & 850 \\
\hline 28 days & 7720 & 9420 & 9300 & 5330 & 7163 & 4465 & 3085 & 2265 & 4140 & 2635 & 2175 \\
\hline 90 days & & & & & & & 4180 & & & & 3070 \\
\hline $\begin{array}{l}\text { Sat. Hydraulic Conductivity } \\
(\mathrm{cm} / \mathrm{s}), \mathrm{k}_{\mathrm{hsat} @ 20 \mathrm{C}}\end{array}$ & 1.6E-09 & 1.6E-09 & NM & 2.2E-09 & 2.1E-09 & 2.2E-09 & 1.5E-09 & NM & 2.2E-09 & 2.7E-09 & 2.0E-09 \\
\hline Shrinkage (vol.\%) & NM & NM & NM & NM & NM & NM & NM & NM & NM & NM & NM \\
\hline $\begin{array}{l}\text { Adiabatic Temperature Rise } \\
\left({ }^{\circ} \mathrm{C}\right)\end{array}$ & $\sim 117$ & & & NM & 90.1 & 68.5 & NM & NM & & 60.1 & NM \\
\hline $\begin{array}{l}\text { Maximum Calorimeter } \\
\text { Temperature for starting } \\
\text { temperature }\left({ }^{\circ} \mathrm{C}\right)\end{array}$ & $\begin{array}{c}\mathrm{T}_{\mathrm{i}}=20.4 \\
\mathrm{~T}_{\mathrm{f}}=104.1 \\
(\mathrm{Mix} 1 \mathrm{H})\end{array}$ & & & & $\begin{array}{c}T_{i}=24.1 \\
T_{f}=97 \\
(\operatorname{Mix} 23 \mathrm{H})\end{array}$ & $\begin{array}{r}\mathrm{T}_{\mathrm{i}}=23.2 \\
\mathrm{~T}_{\mathrm{f}}=\sim 82 \\
(\mathrm{Mix} 24 \mathrm{H})\end{array}$ & & NM & & $\begin{aligned} & \mathrm{T}_{\mathrm{i}}=25.0 \\
& \mathrm{~T}_{\mathrm{f}}=72.4 \\
&(\mathrm{Mix} 25 \mathrm{H})\end{aligned}$ & NM \\
\hline
\end{tabular}


SRNL-STI-2011-00592

Revision 0

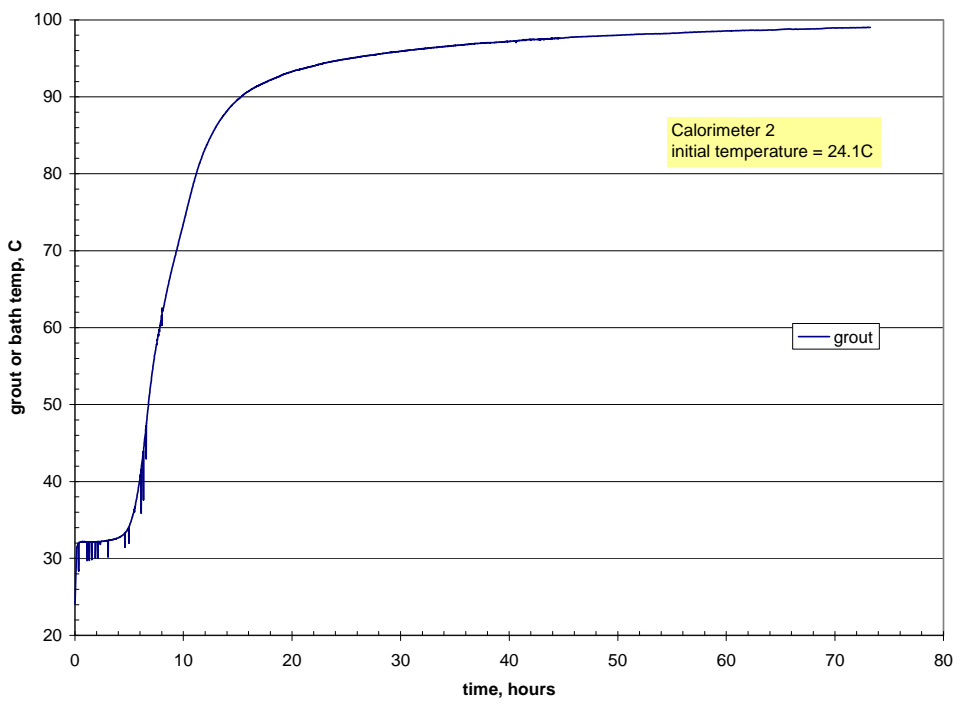

Figure 4-3. Calorimeter results for $1 / 2$ of the Masterflow $^{\circledR}$ substituted with fly ash (Mix 23H).

62.5 Weight Percent Fly Ash Substitution. The strengths for Mix 24, fly ash substituted for 62.5 wt. \% Masterflow ${ }^{\circledR}$, cured for 7 and 28 days were 1975 psi and 4465 psi, respectively. The water to total cementitious material in Mix 24 was 0.36 compared to 0.33 in the base case cooling coil grout mix. The saturated hydraulic conductivity per ASTM D5084 Method C was 2.2E-09 cm/s. Mix 24 had no bleed water. No flow cone rheology or ASTM D6103 spreads were recorded for this mix.

Adiabatic calorimeter results for Mix 24H (same as Mix 24) are plotted in Figure 4-4. This mix had an initial slurry temperature of $23.2^{\circ} \mathrm{C}$. The induction period was about 6 hours after which the temperature rapidly increasing over 20 hours. After 30 hours the temperature rise leveled off. The calorimeter run was continued for 4 more days and peaked at $82^{\circ} \mathrm{C}$ before the test was terminated. The calculated adiabatic temperature rise was calculated to be $68.5^{\circ} \mathrm{C}$ as described elsewhere [12].

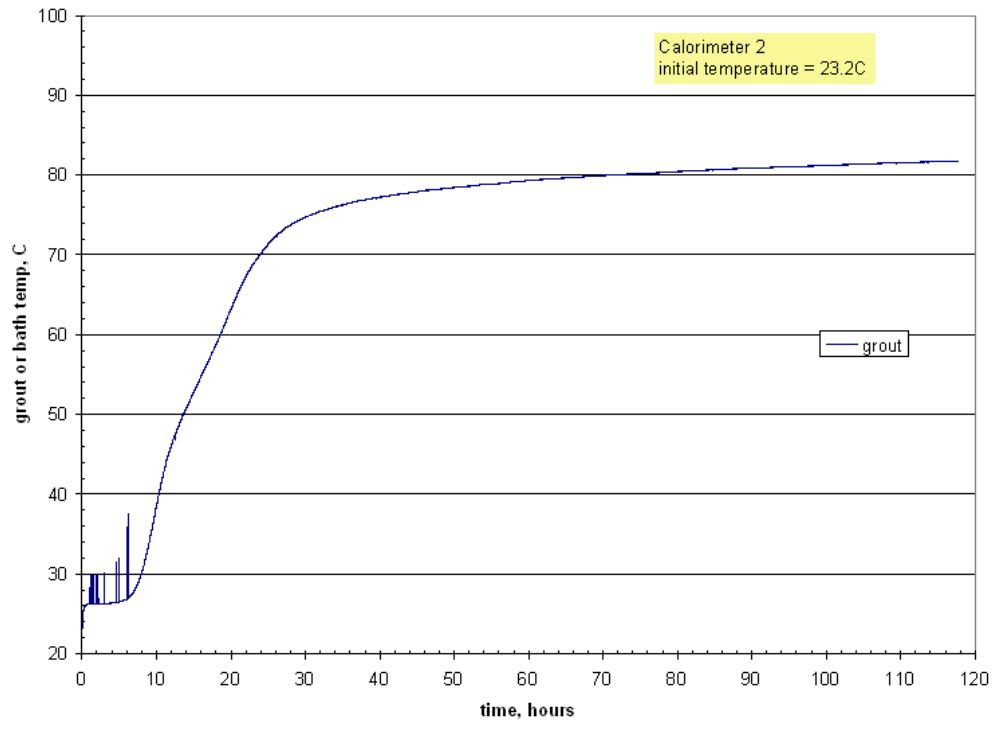

Figure 4-4. Calorimeter results for $5 / 8$ of the MasterFlow ${ }^{\circledR}$ substituted with fly ash (Mix 24H). 
75 Weight Percent Fly Ash Substitution: Mix 25 was formulated by substituting fly ash for 75 wt.\% of the Masterflow ${ }^{\circledR} 816$ in the cooling coil grout mix. Strengths for Mix 25 were 1000 psi and 2635 psi after curing for 7 and 28 days, respectively. The water to total cementitious ratio for Mix 25 was 0.36 (same as Mix 24). The measured saturated hydraulic conductivity per ASTM D5084 Method C was $2.7 \mathrm{E}-09 \mathrm{~cm} / \mathrm{s}$. Again, no flow cone rheology or ASTM D6103 spreads were recorded for this mix. Mix 25 did not bleed.

Adiabatic calorimeter was performed on Mix 25H (same as Mix 25). Results are plotted in Figure 4-5. This mix had an initial slurry temperature of $25^{\circ} \mathrm{C}$. The induction period was about 7 hours before the temperature rapidly increased over the next 26 hours. After 35 hours, the temperature rise slowed significantly. The calorimeter run was about 7.5 days, and the temperature peaked at $72.4^{\circ} \mathrm{C}$. The calculated adiabatic temperature rise was $60.1^{\circ} \mathrm{C}$. The calculation is described elsewhere [12].

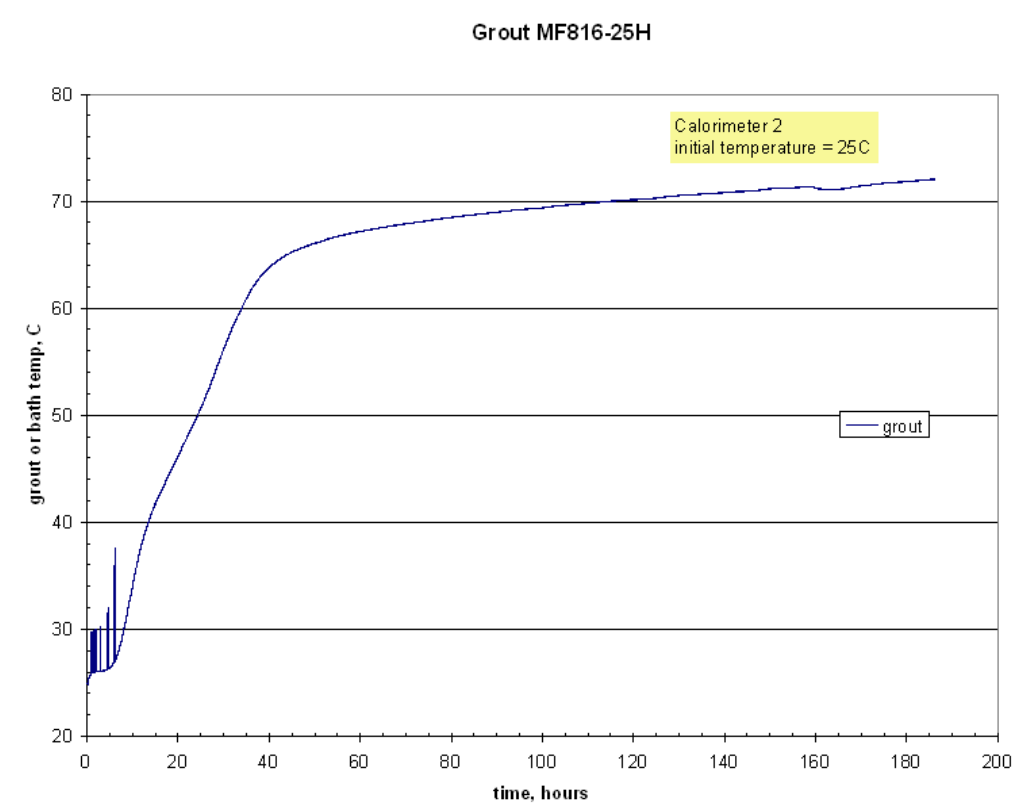

Figure 4-5. Calorimeter temperatures for $3 / 4$ of the Masterflow ${ }^{\circledR}$ substituted with fly ash.

\subsection{Phase 3: Water Extended - Fly Ash Modified Cooling Coil Series}

Phase 3 testing consisted of adding additional water to the modified cooling coil mixes containing 62.5 and $75 \mathrm{wt}$. percent fly ash substitutions for the Masterflow ${ }^{\circledR} 816$ to produce slurries with flow cone rheologies of $\leq 16$ seconds. Three trial mixes were perpared: T1a-62.5FA-0.400 and T1a-75FA-1C$0.400(\mathrm{w} / \mathrm{cm}=0.400)$, and T1a-62.5FA-1C-0.425 $(\mathrm{w} / \mathrm{cm}=0.425)$. See Table 4-2.

Mix T1a-62.5FA-0.400 had an ASTM C939 flow cone value of 16 seconds and a 28 day compressive strength of 3085 psi. The additional water in Mix T1a-62.5FA-0.425 resulted in lower flow cone value of 14 seconds and a lower strength, 2265 psi after curing for 28 days. Both mixes had extended working times as evident by the ASTM D6103 spreads recorded after the 90 minute static period. Mix T1a-62.5FA-0.400 did not bleed. However, Mix T1a-62.5FA-0.425 did segregate as indicated by the presence of bleed water. The saturated hydraulic conductivity for Mix T1a-62.5FA-0.400, measured per ASTM D5084 Method C, was 1.5E-09 cm/s.

Mix T1a-75FA-1C- 0.400 contained 75 wt. \% Class F fly ash substituted for the Masterflow ${ }^{\circledR} 816$. 
The ASTM C939 flow after colloidal mixing was 19 seconds. The ASTM D6103 spread was 15.5 inch after mixing. This mix also had extended working time as illustrated by the static ASTM D6103 results listed in Table 4-2. The spread after a 2 hour static period was 7.6 inches. The air content was 2.1 volume \%. The compressive strengths after 7 days and 28 days of curing were 850 psi and 2175 psi, respectively. The measured saturated hydraulic conductivity per ASTM D5084 Method C was 2.0E-09 $\mathrm{cm} / \mathrm{s}$. This mix did not bleed.

\subsection{Additional Thermal Properties for Equipment Fill Grout Screening Mixes}

Specific heat and thermal conductivity were also determined as part of the thermal property characterization. Results are listed in Table 4-3.

Table 4-3. Summary of thermal properties for representative mixes.

\begin{tabular}{|l|c|c|c|c|}
\hline Thermal Property & $\mathbf{8 1 6 - 1 H}$ & $\mathbf{8 1 6 - 2 3 H}$ & $\mathbf{8 1 6 - 2 4 H}$ & $\mathbf{8 1 6 - 2 5 H}$ \\
\hline MF 816 (lbs/cu ft) & 84.5 & 39.3 & 27.7 & 18.3 \\
\hline Slag Cement Grade 100 (lbs/cu ft) & 9.5 & 7.8 & 7.4 & 7.3 \\
\hline Fly Ash, Class F (lbs/cu ft) & 0 & 39.4 & 46.5 & 54.8 \\
\hline Water $(\mathrm{lbs} / \mathrm{cu} \mathrm{ft})$ & 31 & 28.5 & 29.4 & 28.9 \\
\hline w/cm & 0.33 & 0.33 & 0.36 & 0.36 \\
\hline $\begin{array}{l}\text { Adiabatic Temperature Rise for } \\
\text { complete hydration }\left({ }^{\circ} \mathrm{C}\right)\end{array}$ & $\sim 117$ & & & 60.1 \\
\hline Density $\left(\mathrm{g} / \mathrm{cm}^{3}\right)$ & 1.923 & 1.83 & 1.752 & 1.702 \\
\hline Specific Heat $(\mathrm{cal} / \mathrm{g}-\mathrm{K})$ & 0.341 & 0.358 & 0.396 & 0.372 \\
\hline Specific Heat $(\mathrm{J} / \mathrm{kg}-\mathrm{K})$ & 1428 & 1499 & 1657 & 1558 \\
\hline Thermal Conductivity $(\mathrm{W} / \mathrm{m}-\mathrm{K})$ & 0.80 & 0.89 & 0.92 & 0.89 \\
\hline Thermal Conductivity $(\mathrm{J} / \mathrm{mL})$ & 228 & 247 & 199 & 159 \\
\hline
\end{tabular}




\subsection{CONCLUSIONS}

- Filling Tank 18-F and 19-F ancillary equipment will require a relatively fluid (low viscosity) slurry with extended working times (static and dynamic) and low heat of hydration based on the geometry of the ADMP and other equipment abandoned in the tanks.

- The SRR cooling coil grout, which was selected as the base case mix for filling ancillary equipment, generated too much heat for the equipment fill application, i.e., filling the ADMP which requires about 3 cubic yards of material. It may be too viscous for gravity filling long pipes and other ancillary equipment.

- The mixing method was shown to influence the grout rheology. Laboratory samples prepared by a combination of paddle mixing and high-shear mixing produced more fluid grouts than paddle mixing alone. Colloidal mixers or a combination of paddle and high shear mixers are routinely used for mixing powder-only slurries because shear is required to disperse the fine particles in the fluid.

- Class F fly ash was substituted for up to 75 wt. \% of the Masterflow ${ }^{\circledR} 816$ in the cooling coil grout and the amount of water was increased from water to cementitious ratios of 0.33 to 0.425 . Several trial mixes were characterized.

- Two, fly ash adjusted formulations are recommended for the Tier 1A equipment fill mock up test. Both mixes have properties that exceed the minimum strength and permeability set for the Tank 18$\mathrm{F}$ and 19-F bulk fill grout.

\begin{tabular}{|l|c|c|}
\hline Ingredient & T1a-62.5FA.400 (wt. \%) & T1a-62.5FA.400 (lbs / cu ft) \\
\hline Masterflow $^{(B} 816$ & 24.35 & 26.48 \\
\hline Blast Furnace Slag, grade 100 & 6.49 & 7.06 \\
\hline Fly ash, Class F, ASTM C618* & 40.58 & 44.14 \\
\hline Water & 28.57 & 31.07 \\
\hline w/cm & 0.40 & 0.40 \\
\hline
\end{tabular}

\begin{tabular}{|l|c|c|}
\hline Ingredient & T1a-75FA.400 (wt.\%) & T1a-75FA.400 (lbs / cu ft) \\
\hline Masterflow $^{\circledR} 816$ & 16.23 & 17.36 \\
\hline Blast Furnace Slag, grade 100 & 6.49 & 6.94 \\
\hline Fly ash, Class F, ASTM C618* & 48.70 & 52.07 \\
\hline Water & 28.57 & 30.55 \\
\hline w/cm & 0.40 & 0.40 \\
\hline
\end{tabular}

*Proportions assume a fly ash specific gravity of 2.22 .

- The advantage of the T1a-75FA mix is that it generates less heat during curing. The advantage of the T1a-62.5FA mix is that it is slightly more fluid with the same water to cementitious. Both mixes have lower heat of reactions than the SRR cooling coil grout and will be pumpable.

- At this time, the ease of filling the ADMP is weighted higher than curing temperature which can be managed by engineering controls, i.e., cooling the mix. Consequently, T1a-62.5 is the preferred formulation even if both mixes fill the equipment mock up form. 
- All the equipment fill grouts prepared in this study had strengths and saturated hydraulic conductivities that met or exceeded the strength and saturated hydraulic conductivity requirement for the bulk fill [11].

\subsection{RECOMMENDATIONS}

Mix T1a-62.5FA and Mix T1A-75FA with water to cementitious materials ratios of 0.400 are recommended for the ADMP Tier 1A mock up test. At this time, Mix T1a-62.5FA is the preferred mix because it has a lower ASTM flow cone value. (It is assumed that heat dissipation will be managed by engineering controls if it is determined to be a problem under field conditions.)

Colloidal mixing is the industry standard for mixing powder only slurries. Consequently, a colloidal mixer should be used to prepare grout slurries for the ADMP Tier 1A mock up test. The preferred mixing method is to wet the solids in a paddle mixer and pass the resulting slurry through a colloidal mixer. Once sheared, the slurry can be transferred to a recirculating hold tank and / or pumped to the point of placement.

\subsection{SUGGESTED FUTURE WORK}

Reformulate T1a-62.5FA with more water and substitute very fine aggregate to determine if viscosity improvements can be made. 


\subsection{REFERENCES}

1. $\quad$ SRR Closure Module, 2011. "Industrial Wastewater Closure Module for the Liquid Waste Tanks 18 and 19 F-Area Tank Farm, Savannah River Site," SRR-CWDA-2010-00003, Revision 0, August 2011, Savannah River Remediation Closure and Waste Authority, Aiken, SC, 29808.

2. Chandler, V. A., 2011. "Grout Strategy for Tanks 18 and 19 Closure," SRR-WE-2011-00318, March 9, 2011, Savannah River Remediations, LLC, Savannah River Site, Aiken, SC, 29808.

3. Chander, V. A., 2011. Develop Tank Closure Technology Grout Formulations for Tank(s) 18 \&19, HLE-TTR-2011-008, March 10, 2011, Savannah River Remediation, LLC, Savannah River Site, Aiken, SC, 29808.

4. Stefanko, D. B., Guerrero, H. N., Reigel, M. M., and C. A. Langton, 2011. "Task Technical and Quality Assurance Plan for Developing and Testing Grout Formulations for Filling Tanks 18-F and 19-F and Abandoned Equipment," SRNL-RP-2011-00587, Revision 0, March 22, 2011, Savannah River National Laboratory, Savannah River Site, Aiken, SC, 29808.

5. Hansen, E. K., and A. D. Cozzi, 2008. "Closure of HLW Tanks - Phase 2 Full Scale Cooling Coils Grout Fill Demonstrations," WSRC-STI-2008-00298, Revision 0, June 2008, Savannah River National Laboratory, Savannah River Site, Aiken, SC, 29808.

6. Carter, M., 2011. "Tanks 18 and 19 Internal Equipment Volumes," SRR-LWE-2011-00150, Revision 0, August 11, 2011, Savannah River Remediations, LLC, Savannah River Site, Aiken, SC, 29808.

7. Kane, R. D., 2011. Personal Communication with D. B Stefanko, April 2011, Savannah River Remediations, LLC, Savannah River Site, Aiken, SC, 29808.

8. Langton, C. A., Stefanko, D. B., Serrato, M. G., Blankenship, J. K., Griffin, W. B., Long, J. T., Waymer, J. T., Matheny, D., and D. Singh, 2011. "Use of Cementitious Materials for SRS Reactor Facility In-Situ Decommissioning - 11620," WM 2011, February 27 to March 3, 2011, Phoenix, AZ.

9. Harbour, J. R., Williams, V. J., Hansen, E. K., and W. L. Mhyres, 2008. "Closure of HLW Tanks - Formulation for Cooling Coil Grout," WSRC-STI-2008-0172, Revision 0, April 2008, Savannah River National Laboratory, Savannah River Site, Aiken, SC, 29808.

10. Dixon, K. L. and M. A. Phifer, 2007. "Hydraulic and Physical Properties of Tank Grouts and Base Mat Surrogate Concrete for FTF Closure," WSRC-STI-2007-00369, Revision 0, Savannah River National Laboratory, Savannah River Site, Aiken, SC, 29808.

11. Stefanko, D. B. and C. A. Langton, 2011. "Tank 18 and 19-F Grout Fill Engineering Requirements," SRNL-RP-2011-00977, August 2011, Savannah River National Laboratory, Savannah River Site, Aiken, SC, 29808.

12. Stefanko, D. B. and C. A. Langton, 2011. "Tanks 18 and 19-F Structural Flowable Grout Fill Material Evaluation and Recommendations," SRNL-STI-2011-00551, Revision 0, September 2011, Savannah River National Laboratory, Savannah River Site, Aiken, SC 29808. 


\section{Distribution:}
A. B. Barnes, 999-W
H. H. Burns, 773-43A - Rm.227
B. T. Butcher, 773-43A - Rm. 212
P. E. Carroll, 704-71F
V. A. Chander, 704-70F
L. B. Collard, 773-43A - Rm. 217
D. A. Crowley, 773-43A
W. C. Elkins, 717-11F
S. D. Fink, 773-A
R. W. Forty, 742-5G
B. J. Giddings, 786-5A
M. E. Harrel, 241-108F
J. E. Herbert, 241-108F
C. C. Herman, 999-W
J. P. Hyche, 704-70F
W. L. Isom Jr., 704-26F
R. C. Jolly, Jr., 241-109F
C. A. Langton, 773-43A
S. L. Marra, 773-A
B. A. Martin, 705-1C
A. M. Murray, 773-A
W. L. Mhyre, 717-5N
M. E. Pallon, 717-11F
F. M. Pennebaker, 773-42A
W. Pope Jr., 717-5N
K. H. Rosenberger, 705-1C
J. W. Rush, 241-108F
J. H. Scogin, 773-A
M. G. Serrato, 773-42A
J. L. Steimke, 786-5A
A. J. Tisler, 704-26F
R. O. Voegtlen, 704-71F
J. T. Waymer, 717-5N
W. R. Wilmarth, 773-A
D. C. Wood, 704-26F

(1 file copy \& 1 electronic copy), 773-43A - Rm. 213 